УДК 656.61: 338.1

JEL Classification G30, L52, O21, R11

DOI 10.31375/2226-1915-2021-4-16-31

\section{ВПЛИВОВІ ФАКТОРИ РЕАЛІЗАЦІї ФIНАНСОВОЇ СТРАТЕГIÏ ПІДПРИЄМСТВ ПОРТОВОЇ ДІЯЛЬНОСТІ}

\section{Н.В. Ярова, О.В. Воркунова} к.е.н., доценти,

доценти кафедри «Економіка і фінанси» К.О. Коцюбенко

аспірант кафедри «Економіка і фінанси»

Одеський національний морський університет, Одеса, Україна

Анотація. У статті розглядаються зовнішні та внутрішні фактори, шо визначають вибір фінансової стратегї підприємств портової діяльності.

Були виділені основні області, зміни в яких істотним чином впливають на розвиток морського транспорту, $i$ які необхідно враховувати при формуванні $i$ реалізації національної морськоі політики України $і$ стратегї розвитку окремих підприємств морської галузі.

Більшість існуючих підходів формування та реалізаиії стратегії підприємства, пояснюють можливість оцінити результати $і$ тактику розвитку діяльності підприсмства, передбачити ризики та запобігти можливому банкрутству.

При зміні факторів зовнішнього й внутрішнього середовища одна фінансова стратегія здатна трансформуватися в іншу. Тому підприємство може реалізовувати одночасно декілька фінансових стратегій. Розробка і впровадження заходів фінансової політики в межах окремих стратегій дозволяе чітко визначити єдину концепчію розвитку підприємства в довгостроковій $i$ короткостроковій перспективі, здійснити доиільний вибір механізмів методів досягнення поставлених иілей.

Розглянуті особливості свідчать про складність процесів, що протікають на морському транспорті, що обумовлює особливі вимоги до вибору фінансової стратегії підприємств портової діяльності.

Фінансова стратегія портових підприємств дозволить визначити довгострокові страте гічні цілі, оцінити ресурси, необхідні для їх досягнення, і визначити джерела їх поповнення.

Ключові слова: стратегія, фінансова стра тегія, фактори, підприємства морського транспорту, стратегічний підхід, інвестииійна стратегія, кредитна стратегія.

\footnotetext{
(C) Ярова Н.В. Воркунова О.В., Коцюбенко К.О., 2021
}

УДК 656.61: 338.1

JEL Classification G30, L52, O21, R11

DOI 10.31375/2226-1915-2021-4-16-31

\section{ВЛИЯТЕЛЬНЫЕ ФАКТОРЫ РЕАЛИЗАЦИИ ФИНАНСОВОЙ СТРАТЕГИИ ПРЕДПРИЯТИЙ ПОРТОВОЙ ДЕЯТЕЛЬНОСТИ}

Н.В. Ярова, О.В. Воркунова к.е.н., доценти, доценти кафедри «Економіка і фінанси» К.О. Коцюбенко

аспірант кафедри «Економіка і фінанси»

Одеський національний морський університет, Одеса, Украӥна

Аннотация. В статье рассматриваются внешние и внутренние факторы, определяюшие выбор финансовой стратегии предприятий портовой деятельности.

Были выделены основные области, изменения в которых существенно влияют на развитие морского транспорта, и которые необходимо учитывать при формировании и реализачии национальной морской политики и стратегии развития отдельных предприятий морской отрасли.

Большинство существующих подходов формирования и реализации стратегии предприятия объясняют возможность оченить результать и тактику развития деятельности предприятия, предусмотреть риски и предотвратить возможное банкротство.

При изменении факторов внешней и внутренней среды одна финансовая стратегия способна трансформироваться в другую. Поэтому предприятие может реализовывать одновременно несколько финансовых стратегий. Разработка и внедрение мер финансовой политики в рамках отдельных стратегий позволяет четко определить единую кониепиию развития предприятия в долгосрочной и краткосрочной перспективе, осуществить целесообразный выбор механизмов и методов достижения поставленных иелей.

Рассмотренные особенности свидетельствуют о сложности протекаюших на морском транспорте проиессов, что обуславливает особые требования к выбору финансовой стратегии предприятий портовой деятельности.

Финансовая стратегия портовых предприятий позволит определить долгосрочные стратеги ческие чели, оченить ресурсы, необходимые для ux достижения, $u$ определить источники их пополнения.

Ключевые слова: стратегия, финансовая стратегия, факторы, предприятия морского транспорта, стратегический подход, инвестиционная стратегия, кредитная стратегия. 
UDC 656.61: 338.1

JEL Classification G30, L52, O21, R11

DOI 10.31375/2226-1915-2021-4-16-31

\title{
INFLUENTIAL FACTORS OF IMPLEMENTATION OF FINANCIAL STRATEGY OF PORT ACTIVITIES
}

\author{
Nina Yarova
}

Candidate of Economic Sciences, Associate Professor, Associate Professor of the Department «Economics and Finance» ninayarovaya2017@gmail.com

\section{OlhaVorkunova}

Candidate of Economic Sciences, Associate Professor, Associate Professor of the Department «Economics and Finance» i.ramazanov@gmail.com

Kateryna Kotsiubenko

a PhD student of the Department «Economics and Finance» katerina.kotsyubenko@gmail.com

\section{Odessa National Maritime University, Odessa, Ukraine}

\begin{abstract}
The article considers the external and internal factors that determine the choice of financial strategy of port enterprises.

The main areas were identified, changes in which significantly affect the development of maritime transport, and which must be taken into account in the formation and implementation of the national maritime policy of Ukraine and the development strategy of individual enterprises in the maritime sector.

Most of the existing approaches to the formation and implementation of enterprise strategy, explain the ability to assess the results and tactics of enterprise development, anticipate risks and prevent possible bankruptcy.

When the factors of the external and internal environment change, one financial strategy can be transformed into another. Therefore, the company can implement several financial strategies simultaneously. The development and implementation of financial policy measures within individual strategies allows to clearly define a single concept of enterprise development in the long and short term, to make an appropriate choice of mechanisms and methods to achieve the goals.

The considered features testify to complexity of the processes proceeding on sea transport that causes special requirements to a choice of financial strategy of the enterprises of port activity.

Also considered an important factor in determining the type of financial strategy is the size of the enterprise, which according to the level of concentration and centralization of production and capital of the enterprise is divided into small (small), medium and large (large). The paper considers the influential factors in the development and implementation of the financial strategy of the enterprise depending on its size.

The implementation of the strategy should contribute to the achievement of such a strategic goal as increasing the competitiveness of the enterprise. When developing measures to implement the strategy it is necessary to pay attention to the optimization of the main parameters that determine the competitiveness of the product range, ie quality of service, transportation costs, delivery time, etc.

The formulated strategy for port enterprises is a set of decisions made by management on the basis of basic principles and rules. In other words, strategy is an obligation to act in a certain way: one way and not the other. It is not enough to have only a strategic plan; you need a set of basic principles and rules of conduct for staff at all levels, taking into account the activities in a constantly changing environment.

In essence, the strategy is formulated and is a set of rules for decision-making, which any company, including port enterprises is guided in its activities, ie the strategy can be considered an umbrella, which hides all management functions.

The analysis of literature sources suggests that the financial strategy is a guiding vector of financial management of the enterprise, and without its proper formation of the business entity is very difficult to avoid financial problems in the implementation of production and economic activities in today's globalized, dynamic and competitive market environment.

The financial strategy of port enterprises will allow to define long-term strategic goals, assess the resources needed to achieve them and identify sources of their replenishment. Currently, the successful operation of any enterprise without a well-thought-out strategy is impossible. In order to effectively implement the set goals, it is necessary to identify the most important (priority) activities that ensure the long-term development of the enterprise, and focus efforts on them.

Keywords: strategy, financial strategy, factors, maritime transport enterprises, strategic approach, investment strategy, credit strategy.
\end{abstract}


Постановка проблеми. Стратегія - складна і потужна зброя, за допомогою якої сучасна фірма може протистояти умовам мінливого середовища. Це інструмент, який може серйозно допомогти підприємству, що опинилось в умовах нестабільності. Тому стратегія заслуговуе найсерйознішої уваги як інструмент управління.

Оглядз останніх досліджень і публікацій. Також існують різні підходи формування та реалізації стратегії підприємства, які зображені в наукових працях, Г. Мінцберга, М. Портера, А. Томпсона, А. Стрікланд $[1 ; 3 ; 4 ; 6 ; 9 ; 11 ; 12]$, у тому числі роботи М.Ю. Блінова, В.В. Віннікова, А.М. Котлубай, М. І. Котлубай, А.М. Курлянда, Є. В. Меркт, М.М. Прімачевої, Н.Т. Прімачева, О.Н. Степанова, В.І. Чекаловця та багатьох інших $[7 ; 5 ; 10 ; 13 ; 14]$.

Наприклад американський вчений А.Д. Чандлер вперше ввів поняття «стратегія» в книзі «Стратегія i структура» та комплексно дослідив іiі через співвідношення зовнішнього оточення фірми, план розвитку фірми та іii організаційну структуру управління [11, с. 15].

Необхідно відзначити, що фінансова стратегія - це відносно нове поняття у вітчизняній науці та практиці управління. Водночас слід підкреслити, що в закордонній літературі 3 фінансового управління (зокрема, американській та європейській) $[1 ; 2$; 3 ; 17] поняття «фінансова стратегія» практично відсутнє, науковці оперують такими термінами, як «фінансове планування» $[10,12,13]$, «довгострокові інвестиційні рішення» [8; 9], «управління структурою капіталу»
[8; 10]. У стратегічному управлінні цей термін розглядається виключно як різновид функціональних стратегій.

Мета дослідження. Мета статті обумовлена необхідністю формування фінансової стратегії, спроможності підприємства протистояти негативній дії різних факторів, укріплення конкурентних позицій, створення відповідного механізму, який конкретизується комплексними програмами та напрямами дій щодо нівелювання ризиків, тобто удосконалити основи фінансової стратегії з урахування специфіки підприємств портової діяльності для забезпечення необхідного рівня підвищення конкурентоспроможності на ринку транспортних послуг.

Основний матеріал дослідження. Розвиток підприємницької діяльності в Україні супроводжується не лише кризовими явищами та нестабільністю економічного розвитку, а й неодноразовими намаганнями удосконалити податкову систему, що, як правило, обмежувалось запровадьженням окремих законодавчих актів та було недостатньо адекватним до стану економіки, а тому збільшувалися обсяги тіньового обороту.

При дослідженні кризових явищ економіки України, вітчизняні вчені, як правило, надають перевагу макроекономічним показникам. Але варто зазначити, що при нестабільній ситуації в економіці, скороченні прямих іноземних інвестицій та відмові інвесторів від входження в Україну, зменшенні обсягів кредитування відбувається зниження ділової активності суб'єктів підприємницької діяльності. 
DEVELOPMENT OF MANAGEMENT

AND ENTREPRENEURSHIP METHODS ON TRANSPORT, № 4 (77), 2021
РОЗВИТОК МЕТОДІВ

УПРАВЛІННЯ ТА ГОСПОДАРЮВАННЯ

НА ТРАНСПОРТІ, № 4 (77), 2021
Для управління підприємницькою діяльністю в умовах нестабільної економічної ситуації, необхідно використати можливості економічного аналізу як засобу, який сприяє управлінню підприємством.

Важлива роль аналізу пояснюється можливістю оцінити результати та виробити стратегію і тактику розвитку діяльності підприємства, передбачити ризики та запобігти можливому банкрутству.

Економічний аналіз сприяє дбайливості, умілому витрачанню всіх видів засобів, ліквідації безгосподарності, непродуктивних витрат і втрат». А тому, на думку професора Є. Мниха, у процесах сучасного державного регулювання розвитку економіки в цілому та забезпечення ефективного виробничо-фінансового менеджменту кожного господарчого сегменту необхідно підвищувати якість i оперативність аналітичних досліджень і при цьому «пріоритетною є реалізація його діагностичної та пошукової функції в умовах невизначеності поведінки та мотивації господарчого суб'єкта, перманентних змін нормативно-правового регулювання економічних процесів, зміни співвідношення контрольованості секторів національної економіки, можливостей корпоративного лобіювання економічних інтересів».

Актуальність теми обумовлена необхідністю формування фінансової стратегії, спроможності підприємства протистояти негативній дії різних факторів, укріплення конкурентних позицій, створення відповідного механізму, який конкретизується комплексними програмами та напрямами дій щодо нівелювання ризиків, тобто удосконалити основи фінансової стратегії з урахування специфіки підприємств портової діяльності для забезпечення необхідного рівня підвищення конкурентоспроможності на ринку транспортних послуг.

Стратегія підприємства включає формулювання цілей, концепцій, правил, процедур і моделей досягнення цілей. Стратегія зазвичай не містить детальних кількісних показників.

Стратегічне управління - це процес прийняття і здійснення стратегічних рішень, центральною ланкою якого $\epsilon$ стратегічний вибір, заснований на зіставленні власного ресурсного потенціалу підприємства 3 можливостями й погрозами зовнішнього оточення, в якому вона діє. Стратегію можна розглядати як основну сполучну ланку між тим, що організація хоче досягти (ії цілями), і лінією поведінки, обраної для досягнення цих цілей.

Фінансова стратегія - це сформульована система довгострокових цілей фінансової діяльності компанії та найбільш ефективні шляхи їх досягнення. У цілому, області прийняття рішень групуються в тому ж порядку, у якому їх можна зустріти у балансі та у звіті про прибутки та збитки.

Стратегія - складна і потужна зброя, за допомогою якої сучасна фірма може протистояти умовам мінливого середовища, це інструмент, який може серйозно допомогти підприємству, що опинилось в умовах нестабільності. Тому стратегія заслуговує найсерйознішої уваги як інструмент управління. 
DEVELOPMENT OF MANAGEMENT

AND ENTREPRENEURSHIP METHODS ON TRANSPORT, № 4 (77), 2021
РОЗВИТОК МЕТОДІВ

УПРАВЛІННЯ ТА ГОСПОДАРЮВАННЯ

НА ТРАНСПОРТІ, № 4 (77), 2021
Сьогодні більш популярною $\epsilon$ стратегія, яка містить розробку зон господарювання. Стратегічна зона господарювання (СЗГ) - це автономна частина зовнішнього середовища підприємства, на який воно має (або хоче мати) вихід. Стратегічні господарські центри (СГЦ) - це підрозділи підприємства, на які в силу розподілу відповідальності покладаються функції 3 розроблення конкурентоспроможності виробів і збутових стратегій у рамках, виділених СГЦ. Для того, щоб виділити стратегічні господарські центри, потрібно виявити, у чому зацікавлений потенційний клієнт, за допомогою технічних впроваджень щодо удосконалення продукції, визначається тип клієнта та його місце концентрації. За допомогою аналізу підприємство може на основі даних збільшити свої показники прибутку. Якщо порівнювати базові стратегії й функціональні для підприємства, то можна виділити основну відмінність в тому, що базова стратегія конкретизується на функціональних, але базується на основному напрямку фірми і реалізує основну ціль, яку виділило керівництво.

Велике значення має комплексність розробки стратегії підприємства, оскільки кожен альтернативний варіант передбачає аналіз всіх питань фінансової, ресурсної й організаційної забезпеченості, визначення та узгодження часових та кількісних параметрів.

Виділення ресурсів для досягнення тільки конкретної мети гарантує стабільність реалізації конкурентної стратегії.
Дослідження 3 розробки стратегії конкуренції підприємства полягає у:

- оцінці зовнішніх умов функціонування компанії, тобто в оцінці конкурентних позицій у ринковому сегменті;

- аналізі можливостей компанії 3 реалізації поставлених цілей;

-визначенні чинних альтернатив досягнення цілей, тобто у виборі генеральної стратегії.

Реалізація стратегії повинна сприяти досягненню такої стратегічної мети як підвищення конкурентоспроможності підприємства. При розробці заходів щодо реалізації стратегії необхідно приділяти увагу оптимізації головних параметрів, які визначають конкурентоспроможність комплексу продукції, тобто якості обслуговування, витрат на транспортування, часу доставки тощо Необхідно прагнути до розробки стратегії, що спирається на наявні ресурси й науково-обгрунтоване передбачення ринкової ситуації, що повинно знайти своє відображення в тактиці реалізації стратегії.

Сучасний етап розвитку економіки характеризується поєднанням складних i суперечливих процесів глобалізації бізнесу, обмеженості ресурсів, прискорення технологічних нововведень, внаслідок чого відзначається посилення конкуренції. Ускладнилися проблеми виробництва і розподілу, до них додалися турботи про можливість технологічних проривів, структурних змін економіки й ринку.

Таким чином, на початку XXI століття на перший план вийшли проблеми стратегічні. 
DEVELOPMENT OF MANAGEMENT

AND ENTREPRENEURSHIP METHODS ON TRANSPORT, № 4 (77), 2021
РОЗВИТОК МЕТОДІВ

УПРАВЛІННЯ ТА ГОСПОДАРЮВАННЯ

НА ТРАНСПОРТІ, № 4 (77), 2021
Стратегічне управління часто називають ринковим стратегічним управлінням.

Включення у визначення слова «ринок» означає, що стратегічні рішення повинні більшою мірою враховувати розвиток ринку і зовнішнього оточення, ніж внутрішні чинники. Фірма, що реалізує стратегічне управління, повинна мати зовнішню орієнацію (на споживачів, конкурентів, ринок та ін.).

Це так званий маркетинговий, або ринковий підхід до організації управління на відміну від виробничого підходу, орієнтованого на внутрішні можливості виробництва.

Стратегічне управління означає також, що процес управління повинен бути випереджувальним, а не реактивним. При випереджувальній стратегії менеджери намагаються впливати на події в зовнішньому оточенні, а не просто реагувати на них $[1 ; 3 ; 8$; 9; $10 ; 11 ; 12]$.

Сформульована стратегія для підприємств портової діяльності - це комплекс рішень, прийнятих менеджментом на базі основних принципів i правил. Іншими словами, стратегія це зобов'язання діяти певним чином: таким, а не іншим. Недостатньо мати тільки стратегічний план; потрібен ще поведінки персоналу всіх рівнів 3 урахуванням діяльності в постійно мінливих умовах.

Для підприємств портової діяльності можна виділити наступні переваги стратегічного підходу до управління:

- забезпечення спрямованості розвитку всієї організації за допомогою постановки цілей і завдань;
- гнучка реакція i своєчасні зміни стивідорної компанії, що відповідають виклику 3 боку оточення і дозволяють домагатися конкурентних переваг, що дає можливість організації виживати в довгостроковій перспективі й досягати своїх цілей;

- можливість для керівників оцінювати альтернативні варіанти розподілу ресурсів організації й вживати скоординовані рішення на всіх рівнях управління, пов'язаних 3 чинною стратегією;

- створення середовища, що сприяє активному творчому ініціативному управлінню і протидіє пасивному реагуванню на ситуацію, що змінилася [19].

Стратегія - це всебічний комплексний план, призначений для забезпечення поведінки фірми й досягнення нею цілей.

Завданнями фінансової стратегії $\epsilon$ наступні: визначення способів проведення успішної фінансової стратегії та використання фінансових можливостей; визначення перспективних фінансових взаємовідносин із суб'єктами господарювання та фінансовими інститутами; фінансове забезпечення операційної та інвестиційної діяльності на перспективу; вивчення економічних та фінансових можливостей імовірних конкурентів, розробка та здійснення заходів щодо забезпечення фінансової стійкості; розробка методів управління та способів виходу із кризового стану.

У процесі розробки й реалізації фінансової стратегії варто враховувати динаміку як зовнішніх, так i 
DEVELOPMENT OF MANAGEMENT

AND ENTREPRENEURSHIP METHODS ON TRANSPORT, № 4 (77), 2021
РОЗВИТОК МЕТОДІВ

УПРАВЛІННЯ ТА ГОСПОДАРЮВАННЯ

НА ТРАНСПОРТІ, № 4 (77), 2021 внутрішніх факторів діяльності підприємства.

Фінансова стратегія підприємства згідно зі своєю стратегічною метою забезпечує виконання таких функцій $[11 ; 12 ; 13]$ :

- визначення головної загрози 3 боку конкурентів, правильний вибір напрямків фінансових дій та маневрування для досягнення вирішальної переваги над конкурентами; створення та підготовка стратегічних резервів;

- ранжування та поетапне досягнення мети;

- формування та ефективне використання фінансових ресурсів;

- відповідність фінансових дій економічному стану та матеріальним можливостям підприємства;

- виявлення найефективніших напрямків інвестування та зосередження фінансових ресурсів на цих напрямках.

Вагомим етапом розробки фінансової стратегії $є$ оцінка іï ефективності. Ефективність реалізації фінансової стратегії (як результат покращення фінансових показників діяльності підприємства, підвищення його ринкової вартості, максимізація прибутку, укріплення ділової репутації підприємства, підвищення якості управління фінансовою діяльністю його структурних підрозділів тощо) досягається за умови:

- узгодженості цілей, напрямків і етапів реалізації фінансової та загальної стратегії підприємства;

- адаптивності фінансової стратегії підприємства до прогнозованих змін у зовнішньому підприємницькому середовищі;

- реалізації розробленої під- приємством фінансової стратегії щодо формування власних і залучених зовнішніх фінансових ресурсів $[9 ; 11$; $12 ; 13 ; 14 ; 17 ; 19]$.

Фінансова стратегія передбачає визначення довгострокових цілей фінансової діяльності та вибір найефективніших способів їх досягнення. Цілі фінансової стратегії мають підпорядковуватися загальній стратегії економічного розвитку та спрямовуватися на максимізацію прибутку та ринкової вартості підприємства.

Фінансова стратегія $є$ елементом загальної корпоративної стратегії, що зумовлює розгляд іiі сутності та змісту в контексті загального стратегічного менеджменту.

Розробка фінансової стратегії підприємства має бути органічно вбудована в діяльність із підготовки i реалізації загальної стратегії.

Фінансова стратегія повинна мати управлінську орієнтацію, тобто бути спрямована на досягнення загальної мети управління щодо забезпечення сталого зростання вартості підприємства. 3 іншого боку, завдання фінансової стратегії істотно впливають на формування загальної стратегії розвитку підприємства, оскільки зміна ситуації на ринку спричиняє коригування фінансової, а потім, як правило, і загальної стратегії розвитку підприємства - зворотний зв'язок $[11 ; 12 ; 13]$.

Динамічність факторів зовнішнього середовища спричиняє зміну й внутрішнього середовища підприємства. Це зображується на функціонуванні фінансового механізму управління підприємством. Тому в процесі діяльності підприємства необхідно 
DEVELOPMENT OF MANAGEMENT

AND ENTREPRENEURSHIP METHODS ON TRANSPORT, № 4 (77), 2021
РОЗВИТОК МЕТОДІВ

УПРАВЛІННЯ ТА ГОСПОДАРЮВАННЯ

НА ТРАНСПОРТІ, № 4 (77), 2021 корегувати параметри складових фінансової стратегіï:

- стратегії формування фінан-

сових ресурсів;

- інвестиційної стратегії;

- стратегіï забезпечення

фінансової безпеки;

- структурної стратегії;

- податкової стратегії;

- кредитної стратегії.

Ці стратегї $є$ основними компонентами фінансової стратегії.

Стратегія формування джерел фінансування - центральний компонент фінансової стратегії. Її метою $\epsilon$ створення оптимальних за обсягом, складом i структурою фінансових ресурсів, що забезпечують формування активів, необхідних для реалізації довгострокових планів господарської діяльності підприємства. Цілі, завдання і основні стратегічні рішення цього напряму мають бути спрямовані на фінансове забезпечення реалізації корпоративної стратегії.

Необхідність виділення інвестиційної стратегії як окремого компонента фінансової стратегії визначається значущістю інвестиційних процесів у підвищенні ринкової вартості підприємства, створенні стійких конкурентних переваг, забезпеченні динамічного зростання масштабів i диверсифікації бізнесу. Інвестиційна стратегія визначає пріоритетні напрями й форми інвестиційної діяльності, характер формування інвестиційних ресурсів і послідовність етапів реалізації довгострокових інвестиційних цілей, що забезпечують загальний розвиток підприємства.

Досягнення економічного ефекту коштом інвестицій визначається потенційною їх здатністю генерувати дохід у формі приросту інвестованого капіталу та інвестиційного прибутку. Оцінка інвестиційних проектів дозволяє визначити їх «стратегічну цінність», а саме - врахувати майбутні можливості підприємства залежно від реалізації поточних проєктів. На практиці часто спостерігається паралельне, незалежне існування стратегічного менеджменту, з одного боку, i фінансового менеджменту, 3 іншого [17]. Тому при розгляді інвестиційних проєктів від фінансового менеджера потрібна рівноправна участь у розробці його змісту.

Стратегія забезпечення фінансової безпеки об'єднує політику управління фінансовими ризиками; політику управління структурою капіталу; політику управління рухом грошових потоків. Цілі, завдання й основні стратегічні рішення цього напряму мають бути спрямовані на формування i підтримку основних параметрів фінансової рівноваги підприємства в процесі іï стратегічного розвитку через системи управління фінансовими ризиками. На кожній стадії реалізації фінансової стратегії необхідно здійснювати моніторинг ризиків із метою коригування іiі параметрів.

Кредитна стратегія пов'язана 3 оцінкою обсягу фінансування із зовнішніх боргових джерел, вибором стратегії залучення позикових ресурсів та обгрунтуванням стійких джерел фінансування. Вона повинна бути орієнтована на вибір ефективних фінансових інструментів, розробку стратегії виведення боргових цінних паперів на фондовий ринок і обгрунтування емісії цінних паперів. 
DEVELOPMENT OF MANAGEMENT

AND ENTREPRENEURSHIP METHODS ON TRANSPORT, № 4 (77), 2021
РОЗВИТОК МЕТОДІВ

УПРАВЛІННЯ ТА ГОСПОДАРЮВАННЯ

НА ТРАНСПОРТІ, № 4 (77), 2021
Під час розробки фінансової стратегії підприємства доцільно виділяти стратегічну складову, що зображає структурні зміни при стратегічному управлінні фінансовою діяльністю, - структурну стратегію. Вона пов'язана із вирішенням завдання оптимізації структури активів і капіталу підприємства, що корелює із кредитною й інвестиційною стратегіями через вартість авансованого в компанію капіталу, та 3 оптимізацією структури розподілу прибутку, що передбачає зміни в дивідендній i податковій політиці.

У межах стратегії підвищення якості управління фінансовою діяльністю основну увагу слід зосередити на розробці політики формування фінансової структури. Найбільш ефективним для реалізації фінансової стратегії є створення системи центрів фінансової відповідальності.

Це забезпечує гнучку адаптивність фінансової стратегії до змін і можливість застосування сучасних методів стратегічного фінансового планування.

У реальній ситуації при зміні факторів зовнішнього й внутрішнього середовища одна фінансова стратегія здатна трансформуватися в іншу. Тому підприємство може реалізовувати одночасно декілька фінансових стратегій. Розробка і впровадження заходів фінансової політики в межах окремих стратегій дозволяє чітко визначити єдину концепцію розвитку підприємства в довгостроковій i короткостроковій перспективі, здійснити доцільний вибір механізмів i методів досягнення поставлених цілей.
Наступним вагомим фактором для визначення типу фінансової стратегії є розмір підприємства. В.Д. Базилевич $[11 ; 12 ; 13]$ наголошує, що за рівнем концентрації та централізації виробництва і капіталу підприємства поділяють на малі, середні та великі. Згідно з цим, фінансова стратегія класифікується аналогічним чином (рисунок).

Чим більшим є підприємство, тим складнішими $\epsilon$ мета, засоби іiі досягнення, різноманітними є альтернативні варіанти фінансової стратегії та витрати.

Визначити єдиний підхід до вибору фінансової стратегії складно, адже кожен суб'єкт господарювання має свої особливості. Необхідно формувати таку фінансову стратегію, яка $б$ мінімізувала ризики й сприяла збільшенню його прибутковості, підвищенню конкурентоспроможності та фінансової стійкості на ринку.

Необхідно зазначити, що фінансова стратегія не $\epsilon$ самостійно наявною, вона тісно переплітається 3 іншими функціональними стратегіями, націлена на досягнення місії та постійний розвиток і вдосконалення діяльності суб'єкта господарювання, поглиблення кооперації та встановлення тісних міжгалузевих зв'язків.

Види фінансової стратегії $\epsilon$ індикаторами іiі багатогранної діяльності, розкривають далекоглядні плани підприємства щодо фінансування, зміни фінансової політики, надають інформацію про стійкість i розвиненість галузі, потребу в дотаціях. 


\begin{tabular}{|c|c|c|}
\hline & До складу галузі входять & \\
\hline$\downarrow$ & $\downarrow$ & $\downarrow$ \\
\hline Великі підприємства & Середні підприємства & Малі підприємства \\
\hline \multicolumn{3}{|c|}{$\begin{array}{c}\text { Фактори, необхідні для врахування під час розробки } \\
\text { і реалізації фінансової стратегії підприємства }\end{array}$} \\
\hline$\downarrow$ & $\downarrow$ & 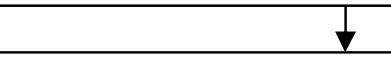 \\
\hline $\begin{array}{l}\text { - масштабність мети; } \\
\text { - значний обсяг фінансо- } \\
\text { вої діяльності; } \\
\text { - високий рівень } \\
\text { диверсифікації } \\
\text { виробництва; } \\
\text { - високий рівень } \\
\text { спеціалізації; } \\
\text { - складність реалізації } \\
\text { стратегії; } \\
\text { - відносна фінансова } \\
\text { стабільність; } \\
\text { - складна організаційна } \\
\text { структура управління; }\end{array}$ & $\begin{array}{l}\text { - можлива зміна місії } \\
\text { та мети залежно від } \\
\text { рівня стабільності } \\
\text { підприємств у галузі; } \\
\text { - застосування іннова- } \\
\text { ційних моделей у біз- } \\
\text { несі; } \\
\text { - помірна довіра бан- } \\
\text { ків до діяльності } \\
\text { таких підприємств у } \\
\text { галузі; } \\
\text { - пошук нових техно- } \\
\text { логічних рішень. }\end{array}$ & $\begin{array}{l}\text { - відсутність глобальної } \\
\text { мети; } \\
\text { - гнучкість виробництва; } \\
\text { - високий рівень } \\
\text { адаптації до мінливих } \\
\text { запитів споживачів; } \\
\text { - відносна фінансова } \\
\text { стійкість; } \\
\text { - концентрація } \\
\text { фінансових ресурсів за } \\
\text { напрямом досліджень; } \\
\text { - швидка переорієнтація } \\
\text { на інші види діяль- } \\
\text { ності. }\end{array}$ \\
\hline
\end{tabular}
капіталу.

\section{Рисунок. Впливові фактори розробки та реалізаиії фінансової стратегії підприємства залежно від його розміру}

Джерело: узагальнено авторами за даними [1; 2; 4; 5; 6; 9;11; 12; 13; 14]

Інформація, зібрана в процесі розробки фінансової стратегії підприємства та результати діяльності суб'єкта господарювання, отримані в результаті реалізації фінансової стратегії, дозволять розкрити потенціал підприємства, сприяючи підвищенню ринкової вартості та максимізації прибутку.

Необхідно відзначити, що в умовах посилення конкурентної боротьби будь-яка стратегія орієнтована на досягнення найвищої прибутковості та зростання ринкової вартості компанії. Це можливо тільки на основі підвищення ефективності процесу формування та розвитку потенціалу стивідорної компанії, який містить у собі різні елементи.

Реалізація стратегії повинна сприяти досягненню такої стратегічної мети як підвищення конкурентоспроможності підприємства. При розробці заходів щодо реалізації стратегії необхідно приділяти увагу оптимізації головних параметрів, які визначають конкурентоспроможність комплексу продукції, тобто якості обслу- 
DEVELOPMENT OF MANAGEMENT

AND ENTREPRENEURSHIP METHODS ON TRANSPORT, № 4 (77), 2021
РОЗВИТОК МЕТОДІВ

УПРАВЛІННЯ ТА ГОСПОДАРЮВАННЯ

НА ТРАНСПОРТІ, № 4 (77), 2021 говування, витрат на транспортування, часу доставлення т.д.

Сформульована стратегія для підприємств портової діяльності - це комплекс рішень, прийнятих менеджментом на базі основних принципів i правил. Іншими словами, стратегія це зобов'язання діяти певним чином: таким, а не іншим. Недостатньо мати тільки стратегічний план; потрібен ще набір основних принципів і правил поведінки персоналу всіх рівнів 3 урахуванням діяльності в постійно мінливих умовах.

По своїй суті сформульована стратегія і є набір правил для прийняття рішень, якими будь-яке підприємство і в тому числі підприємство портової діяльності керується у своій діяльності, тобто стратегію можна вважати парасолькою, під якою ховаються всі управлінські функції.

Проведений аналіз літературних джерел дозволяє стверджувати, що фінансова стратегія $є$ напрямним вектором управління фінансами підприємства, і без їі належного формування суб'єкту господарювання дуже важко оминати фінансові проблеми під час здійснення виробничо-господарської діяльності в сучасному глобалізованому, динамічному i конкурентному ринковому середовищі.

В умовах істотних змін макроекономічних показників, системи державного регулювання ринкових процесів, підвищення нестабільності зовнішнього середовища виникає потреба в розробленні «стратегічного набору» підприємства, до якого належать такі види стратегій: загальна (корпоративна), бізнес, функціональна i операційна. Призначення функціональної стратегї (маркетин- гової, виробничої, фінансової, кадрової чи інноваційної) - забезпечити розв'язання завдань, сформульованих на вищих рівнях управління, з максимальною ефективністю.

Серед функціональних стратегій на особливу увагу заслуговує фінансова стратегія, яка, узгоджуючись iз загальною стратегією організації, виступає ефективним інструментом перспективного управління i фінансовою діяльністю. Однак між ними часто виникають суперечності, тому що процедури розроблення грунтуються на різних, несумісних передумовах: загальна стратегія орієнтується на визначення основного напряму розвитку організації, а фінансова - лише іiі фінансової діяльності і фінансових відносин.

Істотно зростає необхідність формування фінансової стратегії як основи поточного (річного) фінансового плану, розроблення якого для державних підприємств є обов'язковим. Однак реалізація відповідних процедур на стадіях формування фінансової стратегії недостатньо методично розроблена.

Перспективи подальших досліджень полягають у розробці концепції вдосконалення формування та реалізації фінансової стратегії підприємства 3 урахуванням кон'юнктури й тенденцій розвитку ринку, на якому функціонує конкретне підприємство, та факторів ризику, що зумовлені різними трансформаційними процесами, які сьогодні відбуваються в Україні.

Таким чином, фінансова стратегія підприємств портової діяльності дозволить визначити в довгостроковому плані стратегічні цілі, оцінити 
необхідні для досягнення ресурси і встановити джерела їх поповнення. Зараз успішна діяльність будь-якого підприємства без добре продуманої стратегії неможлива. Щоб ефективно реалізувати поставлені цілі, необхід- но визначити найбільш важливі (пріоритетні) види діяльності, що забезпечують перспективний розвиток підприємства, і сконцентрувати на них зусилля.

\section{СПИСОК ЛІТЕРАТУРИ}

1. Бланк І.О., Ситник Г.В., Андрієщь В.С. Управління фінансами підприємств: підручник. К.: Київ. нац. торг.-екон. ун-m, 2017. 792 с. ISBN 978-966-629-846-4.

2. Брижань І.А., Чевганова В.Я. Порівняння методів оцінювання конкурентоспроможності підприємства. "Технологічний аудит та резерви виробництва». Экономика и управление предприятием. Полтава, 2015. № 4/5(24). C. 10-15.

3. Винников В.В. Экономика и эксплуатация морского транспорта: экономика морских перевозок : учебн. пособ. Одесса: Фенікс, 2003. 262 с.

4. Воркунова О.В. Конкурентные стратегии судоходных компаний. Розвиток методів управління та господарювання на транспорті: 3б. наук.пращуь. Одеса: ОНМУ, 2005. № 21. С. 134-144.

5. Воркунова О.В. Формирование конкурентной стратегии судоходной компании Украины. Экономические инновации. Проблемы (Современный инструментарий) развития производственной инфраструктуры: Сб. научн. трудов. Одесса: ИПРЭЭИ НАН Украины, 2007. № 32. C. $166-175$.

6. Воркунова О.В., Рощіна Н.В., Мелай А.І. Ранжсиування стратегічних иілей як основоположний елемент розробки стратегії судноплавної компанії // Розвиток методів управління та господарювання на транспорті: 3б. наук. праиь. Одеса: ОНМУ, 2017. № 1 (58) C. 90-103.

7. Котлубай М.И. Становление морского транспорта в рыночной среде: монографія. Одеса: ИПРЭЭИ НАН Украины, 2005. 224 с.

8. Курлянд А.М., Примачев Н.Т. Экономическая стратегия развития национального торгового судоходства: теория, практика. Одесса: Маяк, 2000. $218 \mathrm{c}$.

9. Кіндрацька Г.І. Стратегічний менеджмент: навч. посіб. Київ : Знання, 2010. $406 c$.

10. Лупак Р.Л., Васильців Т.Г. Конкурентоспроможність підприємства: навч. посібник. Львів: Видавництво ЛКА, 2016. 484 с.

11. Портер М. Конкурентна стратегія. Техніки аналізу галузей $і$ конкурентів / пер.з англ. Н. Кошманенко. К.:Наш формат, 2020. 424 с. 
12. Портер М. Стратегія конкурениії: Методика аналізу галузей ідіяльності конкурентів / пер. з англ. А. Олійника та Р. Скільського. К.: Основи, 1998. 390 c.

13. Чекаловець B.I., Меркт О.В. Формування стратегї розвитку морських торговельних портів у конкурентному середовищі. Стратегія економічного розвитку Украӥни. К.: КНЕУ. 2001. № 4. С. 134-140.

14. Ярова Н.В., Воркунова О.В., Хотєєва Н.В., Скліфос О.С. Основні напрямки вдосконалення методичних основ фінансового планування на підприємствах // Розвиток методів управління та господарювання на транспорті: 3б. наук.праuзь. Одеса: ОНМУ, 2019. № 3 (68). С. 68-86.

15. Ярова Н.В., Воркунова О.В., Ліщуенко В.С., Коцъюбенко К.О. Забезпечення економічної безпеки на підприємствах морського транспорту // Розвиток методів управління та господарювання на транспорті: Зб. наук. праць. Одеса: OHMУ, 2020. № 3 (72). С. 43-61.

16. Ярова Н.В., Воркунова О.В. , Коцююбенко К.О., Ліщенко В.С. Формування методичних положень підвищення конкурентоспроможності контейнерного терміналу на прикладі «ТІС-контейнерний» // Розвиток методів управління та господарювання на транспорті: Зб. наук. праџь. Oдеса: OHMУ, 2020. № 1 (70). C. 71-85.

17. Yarovaya N., Vorkunova O., Ryabovolenko N. Development and calculation of tariffs port works and services: 3б. наук. праць. Дніпропетровський нац. універ. залізничного транспорту ім. акад. В. Лазаряна «Проблеми економіки транспорту». Вип. 12. Дніпро: Дніпропетр, 2016 С. 22-29. ISSN 2309-IX (Print) ISSN 2310-2438 (Online).

18. Yarovaya N.V., Vorkunova O.V., Khotyeyeva N.V. Economic assessment of the alternative energy sources implementation for port enterprises: Economic Annals-XXI. 2017. Vol. 166, Issue 7-8, P. 46-50.DOI: https://doi.org/ 10.21003/ea.V166-09.

19. Brooks D.J. What is security: Definition through knowledge categorisation // Security Journal. 2009. № 3. C. 229-239.

20. Selahattin I., Kitao S. Social Security Reforms: Benefit Claiming, Labor Force Participation, and Long-Run Sustainability // American Economic Journal: Macroeconomics. 2012. № 4. P. 96-127. DOI: 10.1257/mac.4.3.96.

21. Courtney C.C., Levine Ph.B. Recessions, Retirement and Social Security // American Economic Review. 2011. № 101.P. 23-28.DOI: 10.1257/aer. 101.3.23.

22. Lee H. Endress Chapter 3 - Scarcity, Security, and Sustainable Development: Sustainable Economic Development. Resources, Environment and Institutions. 2015. P. 49-66. DOI: 10.1016/B978-0-12-800347-3.00003-0.

23. Lang L.H.P., Stulz R.M., Walkling R.A. Managerial performance, Tobin's Q, and the gains from successful tender offers // Journal of Financial Economics. 1989. № 1. P. 137-154. DOI:10.1016/0304-405X(89)90075-5. 
24. Barnes P. Predicting UK takeover targets: Some methodological issues and an empirical study: Review of Quantitative Finance and Accounting. 1999. № 3. P. 283-302. DOI: 10.1023/A:1008378900054.

25. Powell R.G., Yawson A. Are corporate restructuring events driven by common factors? Implications for takeover prediction // Journal of Business Finance \& Accounting. 2007. № 7-8. P. 1169-1192. DOI: 10.1111/j.1468-5957.2007. 02028.x.

\section{REFERENCES}

1. Blank, I. O., Sytnyk, H. V., \&Andriiets, V. S. (2017). Upravlinnia finansamy pidpryiemstv [Financial management of enterprises].K.: Kyiv. nats. torh.-ekon. un-t[in Ukraine].

2. Bryzhan I.A., \& Chevhanova V.Ya. (2015). Porivniannia metodiv otsiniuvannia konkurentospromozhnosti pidpryiemstva [Comparison of methods for assessing the competitiveness of the enterprise]. "Tekhnolohichnyi audyt ta rezervy vyrobnytstva». Эkonomyka y upravlenye predpryiatyem - "Technological audit and production reserves». Economics and enterprise management. Vol.4/5(24), 10-15 [in Ukraine].

3. Vynnykov, V.V. (2003). Ekonomyka y эkspluatatsyia morskoho transporta [Economics and operation of maritime transport:maritime economics]. Odessa: Feniks [in Russian].

4. Vorkunova, O.V. (2005). Konkurentnble stratehyy sudokhodnblkh kompanyi [Competitive strategies of shipping companies]. Rozvytok metodiv upravlinnia ta hospodariuvannia na transporti - Development of methods of management and administration of transport, 21, 134-144 [in Russian].

5. Vorkunova O.V. (2007). Formyrovanye konkurentnoi stratehyy sudokhodnoi kompanyy Ukrayni[Formation of a competitive strategy of the shipping company of Ukraine]. Ekonomycheskye ynnovatsyy. Problemy (Sovremennyi ynstrumentaryi) razvytyia proyzvodstvennoi ynfrastrukturi - Economic innovations. Problems (Modern tools) for the development of production infrastructure, 32, 166-175 [in Russian].

6. Vorkunova, O.V., Roshchina, N.V., \& Melai A.I. (2017). Ranzhyruvannia stratehichnykh tsilei yak osnovopolozhnyi element rozrobky stratehii sudnoplavnoi kompanii[Features of implementation of competitive strategies in the shipping business].Rozvytok metodiv upravlinnia ta hospodariuvannia na transporti - Development of methods of management and administration of transport, 1 (58), 90-103[in Russian].

7. Kotlubai, M.Y. (2005). Stanovlenye morskoho transporta v rbinochnoi srede [Formation of maritime transport in a market environment]. Odessa: YPRЭЭY NAN Ukraynb [in Ukraine].

8. Kurliand, A.M., \&Prymachev, N.T. (2000). Эkonomycheskaia stratehyia razvytyia natsyonalnoho torhovoho sudokhodstva: teoryia, praktyka [Economic strategy for the development of national merchant shipping: theory, practice]. Odessa: Maiak [in Russian]. 
9. Kindratska H.I. (2010). Stratehichnyi menedzhment [Strategic manage-ment]. K.: Znannia [in Ukraine].

10. Lupak, R.L., \&Vasyltsiv, T.H. (2016). Konkurentospromozhnist pidpryiemstva [Competitiveness of the enterprise]. Lviv: Vydavnytstvo LKA [in Ukraine].

11. Porter, M. Competitive strategy. Techniques of analysis of industries and competitors. N. Koshmanenko (Ed.). K.: Nash format.

12. Porter, M. Competition strategy: Methods of analysis of industries and competitors. A. Oliinyka \& R. Skilskoho (Ed.). K.: Osnovy.

13. Chekalovets, V.I., \&Merkt, O.V. (2001). Formuvannia stratehii rozvytku morskykh torhovelnykh portiv u konkurentnomu seredovyshchi [Formation of a strategy for the development of sea trade ports in a competitive environment]. Stratehiia ekonomichnoho rozvytku Ukrainy - Strategy of economic development of Ukraine, 4, 134-140 [in Ukraine].

14. Iarova, N.V., Vorkunova, O.V., Khotieieva, N.V., \&Sklifos, O.S. (2019). Osnovni napriamky vdoskonalennia metodychnykh osnov finansovoho planuvannia na pidpryiemstvakh [The main directions of improvement of methodical bases of financial planning at the enterprises]// Rozvytok metodiv upravlinnia ta hospodariuvannia na transporti - Development of methods of management and administration of transport, 3 (68), 68-86 [in Ukraine].

15. Iarova, N.V., Vorkunova, O.V., Lishchenko, V.S., \&Kotsiubenko, K.O. (2020). Zabezpechennia ekonomichnoi bezpeky na pidpryiemstvakh morskoho transportu. [Ensuring economic security in maritime transport enterprises] // Rozvytok metodiv upravlinnia ta hospodariuvannia na transporti Development of methods of management and administration of transport, 3 (72), 43-61[in Ukraine].

16. Iarova, N.V., Vorkunova, O.V., Kotsiubenko, K.O. \&Lishchenko, V.S. (2020). Formuvannia metodychnykh polozhen pidvyshchennia konkurentospromozhnosti konteinernoho terminalu na prykladi «TIS-konteinernyi»[Formation of methodical provisions of increase of competitiveness of the container terminal on an example "TIS-container»] // Rozvytok metodiv upravlinnia ta hospodariuvannia na transporti-Development of methods of management and administration of transport, 1 (70), 71-85 [in Ukraine].

17. Yarovaya, N., Vorkunova, O.\& Ryabovolenko, N. (2016). Development and calculation of tariffs port works and services // Problems of transport economic, Issue 12. P.22-29.

18. Yarovaya, N.V., Vorkunova, O.V.\& Khotyeyeva, N.V. (2017). Economic assessment of the alternative energy sources implementation for port enterprises: Economic Annals-XXI. Vol. 166, Issue 7-8. P. 46-50. DOI: https:// doi.org/ 10.21003/ea.V166-09.

19. Brooks, D.J. (2009). What is security: Definition through knowledge categorisation // Security Journal. № 3. P. 229-239.

20. Selahattin I., Kitao S. Social Security Reforms: Benefit Claiming, Labor Force Participation, and Long-Run Sustainability // American Economic Journal: Macroeconomics. 2012. № 4. P. 96-127. DOI: 10.1257/mac.4.3.96. 
21. Courtney C.C., Levine Ph.B. Recessions, Retirement and Social Security // American Economic Review. 2011. № 101. P. 23-28. DOI: 10.1257/ aer.101.3.23.

22. Lee H. Endress Chapter 3 - Scarcity, Security, and Sustainable Development: Sustainable Economic Development. Resources, Environment and Institutions. 2015. P. 49-66. DOI: 10.1016/B978-0-12-800347-3.00003-0.

23. Lang L.H.P., Stulz R.M., Walkling R.A. Managerial performance, Tobin's Q, and the gains from successful tender offers // Journal of Financial Economics. 1989. № 1. P. 137-154. DOI: 10.1016/0304-405X(89)90075-5.

24. Barnes P. Predicting UK takeover targets: Some methodological issues and an empirical study: Review of Quantitative Finance and Accounting. 1999. № 3. P. 283-302. DOI: 10.1023/A:1008378900054.

25. Powell, R.G.\& Yawson, A. (2007). Are corporate restructuring events driven by common factors? Implications for takeover prediction. Journal of Business Finance \& Accounting. № 7-8. P. 1169-1192. DOI: 10.1111/j.14685957.2007.02028.x.

Стаття надійила до редакиії 26.11.2021

Посилання на статтю: Ярова Н.В., Воркунова О.В., Коцюбенко К.О. Впливові фактори реалізації фінансової стратегії підприємств портової діяльності // Розвиток методів управління та господарювання на транспорті: Зб. наук. праць, 2021. № 4 (77).С. 16-31. DOI 10.31375/2226-1915-2021-4-16-31.

Article received 26.11.2021

Reference a JournalArtic: Yarova, Nina, Vorkunova, Olha \& Kotsiubenko, Kateryna. (2021). Influential factors of implementation of financial strategy of port activities.Development of management and entrepreneurship methods on transport.4 (77), 16-31. DOI 10.31375/2226-19152021-4-16-31. 